\title{
Social Entrepreneurship Deserves Better Research
}

\author{
Brett Smith (Miami University of Ohio)
}

\section{KEYWORDS: Entrepreneurship.}

Social entrepreneurs have become celebrated members of the humanitarian community. Using creative thinking and sound business principles, they are tackling vexing social problems such as poverty, global warming and unequal access to education.

President Theodore Roosevelt, an ardent conservationist who helped establish the National Parks Service, was an early social entrepreneur. Florence Nightingale, recognized as the mother of modern nursing techniques, was another. Today's pantheon of social entrepreneurs includes Muhammad Yunus, who developed the concept of microcredit; and Microsoft Founder Bill Gates, whose foundation funds efforts that address social problems.

But while about 400 universities worldwide teach social entrepreneurship, they have done little research on strategies that really move the needle on social problems. Brett Smith, director of the Institute for Entrepreneurship at Miami University of Ohio, says that colleges and universities must collaborate and build a body of research to help the world's social entrepreneurs be more surefooted and successful.

"In social entrepreneurship, we've been focused on sharing success stories from others," said Smith. "But what has worked for one organization may not work for another. Maybe the successful organization just got lucky."

J.P. Morgan and the Global Impact Investing Network estimated in June 2014 that about $\$ 46$ billion in "social impact money" is under management (http://www.inc.com/kimberly-weisul/can-1.5billiontransform-social-entrepreneurship.html) . With that much capital being invested in social entrepreneurship programs, Smith said its managers need more than anecdotal evidence of what works.

"You would not teach chemistry without knowing how different compounds interact, based on research. We need a lot more research in social entrepreneurship to inform both its teaching and its practice."

Smith proposes that social entrepreneurs and academics work together to identify areas where research could do the most good. "The academic community should talk to the practitioners and ask them about what keeps them up at night," he said. "Those needs can inform field-based experiments - using the same rigorous methods and sampling techniques used in other disciplines -- that will help us find real solutions."

In one successful example, Smith cites research into problems with a program that sought to empower Guatamalan women. A company enlisted the women to sell water filtration devices, lamps and other necessities in their villages. Each woman received a prototype to demonstrate to her neighbors. But their inventory kept disappearing.

Through controlled experiments, the research team found that the pilferage stopped when women were asked to spend their own money to buy the prototypes. It gave them an ownership stake and more incentive to keep a close watch on the inventory.

While business schools often compete with one another in their research, Smith suggests that social entrepreneurship is one area in which they should collaborate and share the costs. He envisions an international database that compiles all the universities' research findings, easily accessible to social entrepreneurs.

He said that the cost of continuing to teach social entrepreneurship without solid research is high.

"Without research, we are risking a lot of wasted time and effort," he said. "After throwing a lot of money at a problem like hunger or poverty, are we really saving lives? Research will help us have better, faster outcomes." 


\section{State of the Field of Research in Social Entrepreneurship}

Over the last few years, there has been increasing academic research in the field of social entrepreneurship. Advances in social entrepreneurship research are encouraging. Researchers are beginning to penetrate some of the top empirical (Academy of Management Journal: Kistruck, Sutter, Lount \& Smith, 2013; Mair, Marti, \& Ventresca, 2012; Battilana \& Dorado, 2010) and theoretical journals (Academy of Management Review: Miller et al., 2013; Pache \& Santos, 2010; Peredo \& Chrisman, 2006; Organization Science: Dacin, Dacin, \& Tracey, 2011) especially in the field of management. Academic journals of high quality are dedicating special issues to the topic (for example, Journal of Business Venturing, Entrepreneurship, Theory \& Practice, and Journal of Management Studies). Doctoral seminars are being created to educate the next generation of social entrepreneurship scholars (as evidenced by an intensive seminar created by Tom Lumpkin). Universities are endowing tenure / tenure-track positions and building centers dedicated specifically to social entrepreneurship research (for example, the Base of Pyramid Action Research Center at Miami University in Ohio). This growth is encouraging and has been built upon the foundation of early efforts in the field from pioneering people (e.g., Greg Dees, Johanna Mair, Alex Nicholls, Paul Bloom and Paul Tracey) and events (Research Colloquium on Social Entrepreneurship at Duke University and Oxford University, International Social Entrepreneurship Research Conferences at NYU, Copenhagen and IESE; and the NYU Social Entrepreneurship Research Conference, which recently celebrated its 10th anniversary).

While research in the field of social entrepreneurship is increasing, it substantially lags behind the growth in the curricular, co-curricular and practice areas of social entrepreneurship. Research in the field of social entrepreneurship has been described as "embryonic" and lacking the appropriate methods and samples (Short, Moss, \& Lumpkin, 2009). As a result, the creation of new knowledge in social entrepreneurship is not keeping pace with the implementation of social ventures and initiatives. Unless social entrepreneurial research keeps pace with and contributes to curricular and co-curricular advances, it may undermine the growth and progress in these other important areas. At present, social entrepreneurship research is at an inflection point where it has the potential to be either a catalyst or an inhibitor to the field of social entrepreneurship.

\section{Research as a Means of Legitimacy}

One of the primary ways research can catalyze the field of social entrepreneurship is by increasing legitimacy within and beyond higher education. While universities engage in the activities of teaching and service, academic research - the creation of new knowledge - is often considered one of the most important contributions of higher education. To external audiences, academic research about social innovation creates legitimacy because it contributes to the creation of new products and processes in fields such as medicine and engineering. To internal audiences within universities, academic research creates legitimacy by illustrating how the field of social innovation can contribute to the advancement of knowledge frontiers similar to other disciplines such as psychology, sociology, chemistry or economics. Faculty members are faced with the traditional university requirement: perish or publish. If social entrepreneurship is not seen as a viable path for publication, it will fail to gain traction with tenure / tenuretrack faculty members.

Many doctoral students and tenure-track faculty with an interest in social entrepreneurship are encouraged to pursue their "real" research agenda in more traditional areas and only dabble in social entrepreneurship as a secondary focus. This guidance is provided because incentives and rewards for tenure / tenure track professors are disproportionately weighted toward research in top-tier, disciplinary journals. Research in the field of social entrepreneurship is often hindered by the lack of available data and small sample sizes often required for publication in highly regarded academic journals. While advancements are occurring, more progress in social entrepreneurship research is necessary to increase the overall legitimacy of the field.

This quest for legitimacy of a new academic field is not new. The field of entrepreneurship struggled for decades to gain acceptance into higher education partly because it focused on teaching and service without dedicating enough attention to the importance of academic research. A key turning point occurred as scholars increased both the quality and the quantity of entrepreneurship scholarship, not only through publication in their own journals but also by illustrating how entrepreneurship scholarship may contribute to 
more mainstream journals in established business fields such as management, marketing or finance. Without increasing the centrality of social entrepreneurship research, there is a risk the entire field of social entrepreneurship could become marginalized within universities. Therefore, it is imperative to prioritize the creation of new knowledge through academic research published in top-tier academic journals to legitimize social entrepreneurship within and beyond academic institutions.

\section{Research as a Means of Informing Teaching and Practice}

Another important role for academic research is to serve as the basis for teaching and practice. Often, the new knowledge created through academic research is disseminated initially through academic journals and later through teaching in the classroom. Given that curricular and co-curricular programs are far outpacing academic research in social entrepreneurship, an important question arises: what is being taught in social entrepreneurship courses? To fill the void of academic research in social entrepreneurship, instructors often turn to knowledge generated in adjacent disciplines (such as entrepreneurship) or disciplines that address problems (such as social movements from sociology). While these may be important inputs into the process, it is also likely that some unique issues arise directly related to social entrepreneurship. In this way, the teaching of social entrepreneurship needs to be informed by academic research of scientifically rigorous, tested theories to explain how and why certain aspects of social entrepreneurship occur. To more fully deliver on this promise, social entrepreneurship research needs to move beyond descriptive cases studies and small samples of successful social entrepreneurs to better explain how and why some social entrepreneurs are more effective than others.

Academic research can also serve as an important means to inform practice. To do so, social entrepreneurs can more fully engage in and appreciate the rigor of academic research. For example, practitioners can communicate with researchers about the practical problems that need to be resolved and work with academics on designing effective interventions to test solutions to the problems. Likewise, academic researchers need to design academic studies around practical problems and need to communicate their research results in a way that gives a wider audience access to the knowledge and application of their findings. For example, in addition to publishing findings in academic journals, researchers could also disseminate findings in practitioner journals such as Harvard Business Review, Stanford Social Innovation Review, or MIT's Innovations. Further, case studies and other teaching materials could be developed based on academic research and studies rather than on their own. In this way, the field of social entrepreneurship could improve the quality and effectiveness of teaching and practice by leveraging the new knowledge created through academic research.

\section{The Future of Social Entrepreneurship Research}

While the growth of social entrepreneurship research is encouraging, much work needs to be done for academic research to serve as a catalyst for the field of social entrepreneurship.

First, many more faculty members must view social entrepreneurship as viable avenue for academic research in top-tier journals. Impediments to conducting research need to be reduced through such initiatives as the development of a large-scale, internationally representative database. Similarly, the costs of conducting research must be shared through the collaboration of faculty from multiple universities and funding organizations that need to include social entrepreneurship research within the scope of their funding criteria. For example, in the study of commercial entrepreneurship, the Panel Study of Entrepreneurial Dynamics (PSED) was created through the participation of 18 universities and two funding organizations -National Science Foundation and Kauffman Foundation -- to improve the scientific study of how people start businesses. By making the PSED publicly available, many researchers leveraged the PSED database to address research questions with a longitudinal, nationally representative sample of nascent entrepreneurs. The development of a similar database for social entrepreneurs may reduce barriers to conducting social entrepreneurship research and help increase research that further legitimizes the field of social entrepreneurship.

Second, the quality of the social entrepreneurship research must improve through more rigorous methods and samples. Innovative approaches from other fields like development economics - such as field-based 
experiments and multi-method designs - must be leveraged to understand what is happening and why it is happening, and add to our knowledge of social entrepreneurship. Miami University $(\mathrm{OH})$ created the Base of the Pyramid Action Research Center (BOPARC) to conduct field-based experiments aided by multi-methods to address practical problems with leading social entrepreneurial organizations (e.g., Room to Read) and models (e.g., micro-consignment model). Building on the initial success of BOPARC, the Social Innovation Research Lab (SIRLab) provides a multiuniversity approach to field-based experiments. The use of better methods and samples will improve the quality of the created knowledge, leading to higher quality publications and better knowledge to inform teaching and practice.

Third, the teaching, research and practice of social entrepreneurship must be linked more strongly. These links should create a two-way street where academics and practitioners / students come together to create and to disseminate knowledge. Universities need to create a role for the translation function that must occur to facilitate the rigor, relevance and accessibility of academic research for teaching and practice. Moving beyond scholarship of discovery, faculty members are contributing to knowledge creation in different forms of scholarship (Boyer, 1990), including scholarship of engagement and scholarship of teaching and learning. At Middlebury College, faculty members are encouraging the integration of social entrepreneurship into the liberal arts, including the humanities, and are extending traditional forms of scholarship to include practitioner articles in outlets such as Stanford Social Innovation Review and open-source outlets to communicate the value and role of social entrepreneurship. In this way, broader definitions allow for more inclusive scholarship and incorporate contributions from areas such as the humanities that have much to contribute but have been underrepresented in the field of social entrepreneurship.

Fourth, we must move beyond disciplinary research to more interdisciplinary research that locates the social problem faced by the social entrepreneur or society at the center of the research design. At Marquette University, faculty members are coming from a number of different disciplines to address questions about the meaning of social entrepreneurship and social innovation. For example, social entrepreneurship is incorporated into a writing sequence in English and also integrated in many areas across campus as a means to link social entrepreneurship to the overall institutional mission of the university. Such an approach allows for the full-complement of the many different academic disciplines to contribute to the creation of new knowledge about products and processes to address persistent social problems.

In this way, social entrepreneurship research can serve as a catalyst - within and beyond the university - to more fully deliver on the potential of the field of social entrepreneurship.

\section{References}

Battilana, J. \& Dorado, S. (2010). Building sustainable hybrid organizations: The case of commercial microfinance organizations. Academy of Management Journal, 53: 1419-1440.

Boyer, E. (1990). Scholarship reconsidered. Carnegie Foundation for the Advancement of Teaching.

Dacin, M., Dacin, P., \& Tracey, P. (2011). Social entrepreneurship: A critique and future directions. Organization Science, 22: 1203-1213

Kistruck, G., Lount, R., Sutter, C. \& Smith, B. (2013). Mitigating principal-agent problems in Base-of-thePyramid markets: An identity spillover perspective. Academy of Management Journal, 56: 659-682.

Mair, J., Marti, I, \& Ventresca, M. (2012). Building inclusive markets in rural Bangladesh: How intermediaries work institutional voids. Academy of Management Journal, 55: 819-850.

Miller, T., Grimes, M., McMullen, J. \& Vogus, T. (2012). Venturing for others with heart and head: How compassion encourages social entrepreneurship. Academy of Management Review, 37: 616-640.

Pache, A.C. \& Santos, F. (2013). Inside the hybrid organization: Selective coupling as a response to competing institutional logics. Academy of Management Journal, 56: 972-1001.

Peredo, A. \& Chrisman, J. (2006). Toward a theory of community-based enterprise. Academy of Management Review, 31: 309-328.

Short, J., Moss, T., \& Lumpkin, G. (2009). Research in 
social entrepreneurship: Past contributions and future opportunities. Strategic Entrepreneurship Journal, 3: 161-194.

[i] An earlier version of this paper was published in Ashoka Trends in Social Innovation (2014). 